\title{
Ozonation of Yarn dyed Wastewater in a Continous Stirred Tank Reactor : Kinetic Study and Performance Optimisation
}

\author{
Lieke Riadi ${ }^{1,2^{*}}$, Andrian Sugiharto ${ }^{1}$, and Hana Gondokusumo ${ }^{1}$ \\ ${ }^{1}$ Departemnet of Chemical Engineering, The University of Surabaya ,Jl.Raya Kalirungkut ,Surabaya 60239, Indonesia \\ ${ }^{2}$ Center for Environmental Studies, The University of Surabaya ,Jl.Raya Kalirungkut, Surabaya 60239, Indonesia
}

\begin{abstract}
This paper describes the ozonation process in yarn dyed wastewater using continuous stirred tank reactor with the objective to study the kinetic of COD degradation at various volumetric flow rate $(30,50,70 \mathrm{ml} / \mathrm{min})$ and ozone concentration $(2.70 \%, 4.25 \%, 5.86$ $\% \mathrm{~mol} / \mathrm{mol})$. The wastewater which was collected from a yarn dying process located in Surabaya area was pretreated by electrocoagulation prior to ozonation process. The electrocoagulation process was carried out to reduce the color intensity and total suspended solid. The pretreated wastewater was then processed using ozonation for 2.5 hours. The result showed that at various concentration of ozone, maximum COD removal was $90.78 \%$ which was achieved at $5.86 \% \mathrm{~mol} / \mathrm{mol}$ of Ozon and volumetric flow rate $50 \mathrm{ml} / \mathrm{min}$. It was found that the degradation process followed the pseudo-first order kinetic model. The obtained pseudo-first order rate constants for volumetric rate of $50 \mathrm{mil} / \mathrm{min}$ were $0.0307 \mathrm{~min}^{-1}, 0.0419 \mathrm{~min}^{-1}$ and 0.053 $\mathrm{min}^{-1}$ for ozon concentration of $2.70 \%, 4.25 \%, 5.86 \% \mathrm{~mol} / \mathrm{mol}$ respectively. The residence time were 41 minutes, 31 minutes and 23 minutes for ozone concentration of $2.70 \%, 4.25 \%, 5.86 \%$ $\mathrm{mol} / \mathrm{mol}$ respectively. These findings offers an alternative treatment for wastewater containing dyes.
\end{abstract}

\section{Introduction}

Yarn dyeing industry generates large amount wastewater with high color intensity, high chemical oxygen demand (COD), suspended solids and some heavy metals. The dyes may be carcinogenic and mutagenic which are harmful for human beings. The dyes have a complex aromatic molecular structure which is difficult to biodegrade $[1,2]$. Physical methods which are known to be used in the treatment usually used as primary treatment such as precipitation,adsorption, and chemical coagulation. Since the COD content is quite high enough after the primary treatment, it is further treated by other treatment such as chemical degradation or biodegradation. Biological process is slower, requires large area especially in the process of color removal. The electrochemical technique has been used which removed color but not the COD content [3].

Chemical processes are generally more simple in application and need oxidizing agents such as hydrogen peroxide, ozone and hydroxyl radicals. The process is known as Advanced Oxidation Process. Ozone is a strong oxidation agent $\left(\mathrm{E}^{\mathrm{o}}=2.07 \mathrm{~V}\right)$ which has been used to oxidize wastewater contained phenols and cyanides [4]. Due to its dipolar nature, ozone can either react as an electrophilic and nucleophilic agent or cause dipolar cycloaddition with most of the compounds with double bonds [5]. As a powerful oxidizing agent, ozone can breakdown the double bonds of dye chromophores and also other functional groups such as complex aromatic rings of dyes [6]. The wastewater used in this study was collected from yarn dyeing industry located in southern part area of Surabaya.

The mechanism of ozonation, follow two main paths: a direct path corresponding to the action of molecular ozone, and an indirect path is a result from the decomposition of ozone to radicals, in which the reaction is initiated by hydroxyl ions $\left(\mathrm{OH}^{-}\right)$[7].The wastewater has a lot of azo dyes which is an aromatic double bonds as can be seen in Figure 1. The wastewater was treated using electrocoagulation in batch system prior ozonation.

The characteristic of wastewater prior and after electrocoagulation is shown in Table 1. The allowable concentration of COD in wastewater to be discharged is $150 \mathrm{ppm}$ as stated in East Java regional government regulation (SK Gub 72/2013). The objectives of this work are to study the effect of ozone concentration, flow rate of wastewater in COD removal efficiency. The $\mathrm{pH}$ and conductivity profiles of wastewater during ozonation were also observed. This work also studied kinetic model for COD removal in a Continuous Stirred Tank Reactor (CSTR) mode.

\footnotetext{
Corresponding author: lieke@staff.ubaya.ac.id
} 


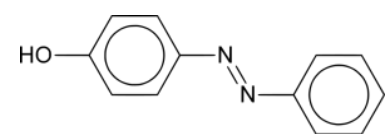

Fig.1. chemical structure of azo dye.

Table 1. Characteristic of wastewater

\begin{tabular}{|c|c|c|}
\hline Parameter & $\begin{array}{c}\text { Prior } \\
\text { electrocoagula } \\
\text { tion }\end{array}$ & $\begin{array}{c}\text { After } \\
\text { electrocoagula } \\
\text { tion }\end{array}$ \\
\hline Color OD 498 & 1.3117 & 0.0053 \\
\hline TSS [mg/L] & 18,780 & 2,913 \\
\hline COD [ppm] & 745 & 334 \\
\hline $\mathrm{pH}$ & 12 & 8.5 \\
\hline $\begin{array}{c}\text { Conductivity } \\
{[\mathrm{mS} / \mathrm{cm}]}\end{array}$ & 19.35 & 13.50 \\
\hline
\end{tabular}

\section{Materials and Methods}

\subsection{Materials}

\subsubsection{Wastewater}

Wastewater used in this study was collected form yarn dyeing industry located in southern part area of Surabaya. Since the fluctuation of wastewater characteristic, we have two types of wastewater with different COD.The wastewater used to study effect of flow rate had a COD content about $1300 \mathrm{ppm}$ prior electrocoagulation and $780 \mathrm{ppm}$ after electrocoagulation. Other experiments for parameter of ozone concentration and $\mathrm{pH}$ used wastewater with characteristic as shown in Table 1.

\subsubsection{Ozone and oxygen gases}

Ozone was generated from oxygen by Ozone generator (Viresco, Singapore). The ozone output was adjusted from $0-50 \mathrm{~g} / \mathrm{h}$. The oxygen ouput at $5-15 \mathrm{~L} / \mathrm{min}$. The exit port of ozone generator is connected with deep tube and the ozone gas was delivered to the reactor through tube sparger at the bottom of the reactor. The residual ozone was decomposed by trapping excess ozone at the reactor outlet which is connected to $2 \%$ potassium iodide (KI) solution trap.

\subsection{Combined Electrocoagulation and Continuous Stirred Tank Reactor (CSTR)}

An electrocoagulation (EC) reactor with $1.5 \mathrm{~L}$ volume was used. The real wastewater was taken form yarn industry located in Surabaya, East Java province, Indonesia. Anode and Cathode $\mathrm{Al} / \mathrm{Al}$ was used with a distance between two electrodes was $2 \mathrm{~cm}$. The electrodes were connected to DC power supply. The size of Alumunium plate was $8 \mathrm{~cm} \times 8 \mathrm{~cm}$, with a thickness of $2 \mathrm{~mm}$.

The EC process was run for 10 minutes and used a method as described by Riadi et al. [8]. The effluent from EC process was then collected and used as influent for ozonation process. A CSTR with $1250 \mathrm{~mL}$ volume was developed using a glass vessel connected to collection tank of effluent from electrocoagulation process. Ozone fed to CSTR from ozone generator and diffused through a diffuser in a bottom of reactor.The system used in the experiment can be seen in Figure 2.

\subsection{Analysis of wastewater}

COD was measured using closed reflux, colorimetric method based on Standard Methods for the Examination of Water and Wastewater [9]. Total Suspended solid was measured using dried method, color measurement was conducted using UV-Vis spectrophotometer at $498 \mathrm{~nm}$ wavelength based on Standard Methods for the Examination of Water and Wastewater [9].

The wastewater was also analysed using GC-MS to find out the components of dye in the wastewater. The GC serie is Agilent 7890 and the MS is agilent 5975, the column used was HP5MS, 30 m length and the diameter is $0.2 \mu \mathrm{m}$. Ozone concentration trapped in KI solution was measured using sodium thiosulfate tritation procedure. Ozone consumed was calculated as: Ozone produced - Ozone trapped in KI trapper, with an assumption there is no ozone left to the environment.

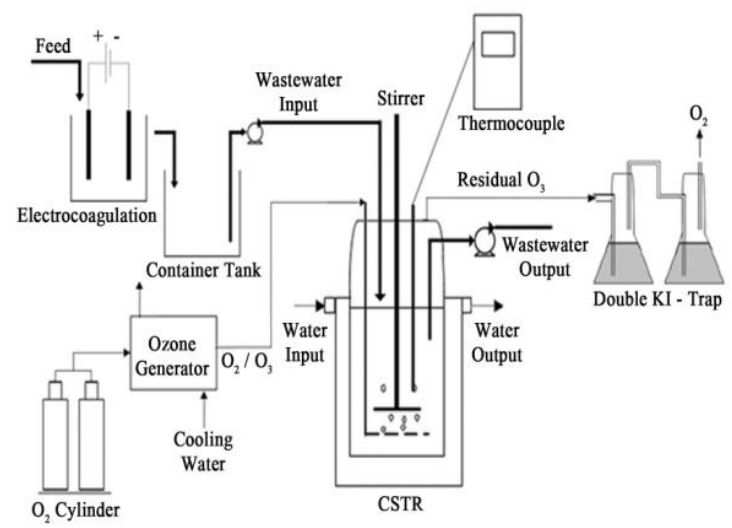

Fig. 2. Scheme of ozonation in CSTR

\subsection{Ozonation process}

Ozonation process was carried out to evaluate the performance of COD degradation in a CSTR with working volume of $800 \mathrm{~mL}$, and agitation of $200 \mathrm{rpm}$ at $30^{\circ} \mathrm{C}$. The parameters used in the experiment were volumetric flowrate of wastewater $(30,50,70$ $\mathrm{ml} /$ minutes) with ozone concentration of $4,25 \%$ $\mathrm{mol} / \mathrm{mol}$; the effect of ozone concentration $(2,70,4,25$, $5,86 \% \mathrm{~mol} / \mathrm{mol}$ ) was studied with wastewater flow rate of $50 \mathrm{~mL} / \mathrm{min}$. Samples were taken periodically for 2.5 
hours. $\mathrm{pH}$ and conductivity were measured using $\mathrm{pH}$ meter and counductivity-meter from METTLER.

\section{Results and Discussions}

\subsection{Effect of ozone concentration}

Experiments were carried out at $2.7 \% \mathrm{~mol} / \mathrm{mol}, 4.25 \%$ $\mathrm{mol} / \mathrm{mol}$ and $5.86 \% \mathrm{~mol} / \mathrm{mol}$ of ozone concentration with the wastewater flow rate (v) of $50 \mathrm{~mL} /$ minute. Ozone was assumed dissolved perfectly in wastewater, so the reaction can be considered as homogenous reaction. Since ozone was fed in excess then the reaction (1), is a pseudo first order reaction with $\mathrm{z}=$ stochiometri coefficient.

$$
\mathrm{O}_{3}+\mathrm{z} \text { COD }---\rightarrow \text { degraded pollutant }
$$

In a CSTR model [10], we get :

$$
\tau=\frac{V}{v_{0}}=\frac{C a_{o} X}{k C a}
$$

By rearranging equation (2), we get :

$$
k=\frac{c a_{o}-c a_{f}}{\varepsilon c a_{f}}
$$

Cao $=$ initial $\mathrm{COD}$ concentration, $\mathrm{Ca}_{\mathrm{f}}=$ final COD concentration, $\tau=$ space time, $\mathrm{k}=$ first order kinetic constant.

The pseudo first order model fit with the data at the first 10 minutes of ozonation (Fig.3), hence based on the equation (3), we can calculate the pseudo first order kinetic constant at different ozone concentration as can be seen in Table 2 .

Table 2. Pseudo-first order kinetic constant at different $\left[\mathrm{O}_{3}\right]$

\begin{tabular}{|c|c|c|c|}
\hline $\begin{array}{c}\text { Ozone } \\
{[\% \mathrm{~mol} / \mathrm{mol}]}\end{array}$ & $\begin{array}{c}\mathrm{C}_{\mathrm{AO}} \\
{[\mathrm{ppm}]}\end{array}$ & $\begin{array}{c}\mathrm{C}_{\mathrm{AS}} \\
{[\mathrm{ppm}]}\end{array}$ & $\begin{array}{c}\mathrm{k}^{\prime} \\
{\left[\text { minute }^{-1}\right]}\end{array}$ \\
\hline 2.70 & 337.967 & 225.91 & 0.031 \\
\hline 4.25 & 345.523 & 206.65 & 0.042 \\
\hline 5.86 & 332.930 & 180.15 & 0,053 \\
\hline
\end{tabular}

concentration at steady state, $\mathrm{k}^{\prime}=$ pseudo first order kinetic constant which is $=\mathrm{kx} \mathrm{C}_{\mathrm{O} 3}$.

The value of $\mathrm{k}^{\prime}$ using $5.86 \% \mathrm{~mol} / \mathrm{mol}$ ozone was similar to $\mathrm{k}$ ' from batch experiment which was 0.0521 $\mathrm{min}^{-1}$. The pseudo first order kinetic constant in batch experiment was also obtained at the first 10 minutes of ozonation and also used $5.86 \% \mathrm{~mol} / \mathrm{mol}$ ozone [11]. Result from the experiment showed that higher concentration of ozone will result in higher COD removal efficiency as can be seen in Fig.3. If we used 150 minutes timeline from the experiments, the percentage removal of COD were $33.17 \% ; 49.57 \%$ and $90.78 \%$ for $2.7 \%, 4.25 \%, 5.86 \% \mathrm{~mol} / \mathrm{mol}$ ozone respectively.

Since the allowable COD concentration to be discharged is $150 \mathrm{ppm}$ (East Java province regulation), then we can recalculate the space time and reactor volume needed using the value of k' as stated in Table 2 .
To get $150 \mathrm{ppm}$ of COD concentration in the wastewater at $50 \mathrm{~mL} / \mathrm{min}$ flowrate $(v)$, we need bigger reactor volume $(\mathrm{V})$ and longer space time $(\tau)$ for lower ozone concentration (Table 3 ).

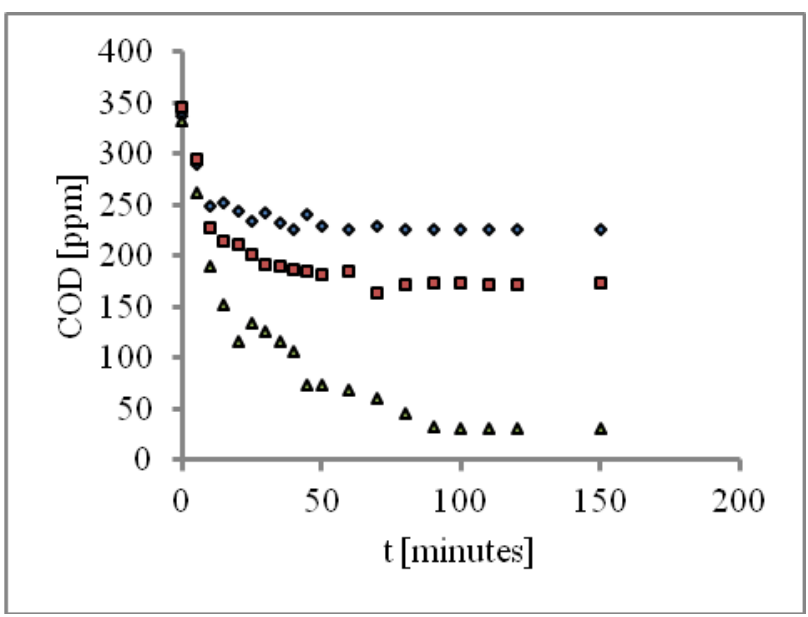

Fig.3. COD profile at different ozone concentration,( $\bullet$ ) 2.7\% Ozone, (•) $4.25 \%$, Ozone ( $\mathbf{\Delta}$ ) $5.86 \%$ Ozone.

Table 3. Value of pseudo first order kinetic constant at different ozone concentration

\begin{tabular}{|c|c|c|c|c|c|}
\hline $\begin{array}{l}\text { Ozone } \\
\% \\
\mathrm{~mol} / \mathrm{mol}\end{array}$ & $\begin{array}{c}\mathrm{C}_{\mathrm{AO}} \\
(\mathrm{ppm})\end{array}$ & $\begin{array}{c}\mathrm{C}_{\mathrm{AS}} \\
(\mathrm{ppm})\end{array}$ & $\begin{array}{c}\mathrm{k}^{\prime} \\
\mathrm{min}^{1}\end{array}$ & $\begin{array}{c}\tau \\
(\mathrm{min})\end{array}$ & $\begin{array}{c}\mathrm{V} \\
(\mathrm{ml})\end{array}$ \\
\hline 2.70 & 337.96 & 150 & 0.031 & 41 & 2.021 \\
\hline 4.25 & 345.52 & 150 & 0.042 & 31 & 1.552 \\
\hline 5.86 & 332.93 & 150 & 0,053 & 23 & 1.151 \\
\hline
\end{tabular}

\subsection{Effect of wastewater volumetric flow rate.}

The ozone concentration used in the experiment was $4.25 \% \mathrm{~mol} / \mathrm{mol}$, the flow rate variable were $30,50,70$ $\mathrm{mL} /$ minute. Result from this study showed that higher flow rate of wastewater will result in lower removal of COD as can be seen at Table 4 . The experiment result of COD profile was similar to that in simulated model as written in equation (3) as presented in Fig.4. The best removal of COD was at flow rate of $30 \mathrm{~mL} / \mathrm{min}$. By working with smaller flow rate at constant volume, we have bigger space time and we will have higher conversion in a single CSTR.

However, implementation in the field with smaller flow rate may consider the size of reactor which is not favorable from economic point of view. Hence, performance optimization as written in Table 3 gave us an insight that working with high concentration of Ozone is favorable than lower volumetric flowrate. Therefore, a volumetric flow rate of $50 \mathrm{~mL} / \mathrm{min}$ and $5.86 \% \mathrm{~mol} / \mathrm{mol}$ ozone was a suitable parameter for a CSTR with 1150 $\mathrm{mL}$ volume to reduce the COD up to an allowable level to be discharged by the regulation $(150 \mathrm{ppm})$. The optimum performance of the reactor to maintain COD level at $150 \mathrm{ppm}$, was in $1150 \mathrm{~L}$ volume of CSTR, 200 $\mathrm{rpm}$ of agitation, $50 \mathrm{~mL} / \mathrm{min}$ volumetric flow rate, 23 minutes of space time and $5.86 \% \mathrm{~mol} / \mathrm{mol}$ of ozone. 
Table 4. Removal of COD (\%) at different flow rate using $4.25 \% \mathrm{~mol} / \mathrm{mol}$ Ozone

\begin{tabular}{|c|c|}
\hline flow rate $(v), \mathrm{mL} / \mathrm{min}$ & \% removal of COD \\
\hline 30 & 80.09 \\
\hline 50 & 77.6 \\
\hline 70 & 67.84 \\
\hline
\end{tabular}

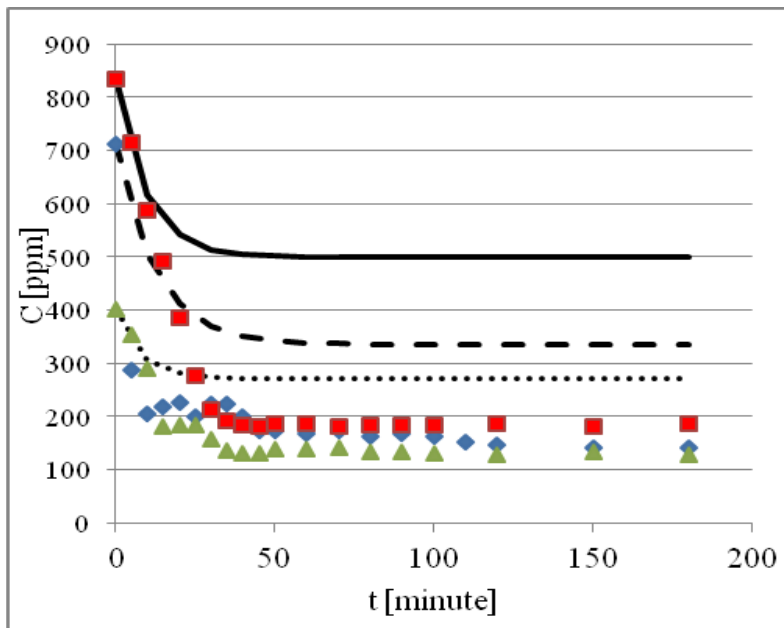

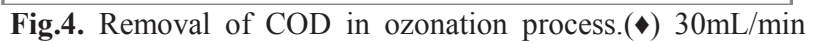
experiment, $(\boldsymbol{\square}) 50 \mathrm{~mL} / \mathrm{minexperiment},(\boldsymbol{\Delta}) 70 \mathrm{~mL} / \mathrm{min}$ experiment. (---)30mL/min,model, (-) $50 \mathrm{~mL} / \mathrm{min}$, model, (....) $70 \mathrm{~mL} / \mathrm{min}$, model

\subsection{Profile of $\mathrm{pH}$ and conductivity during ozonation process}

There is no significant change of $\mathrm{pH}$ and conductivity during ozonation process, $\mathrm{pH}$ and conductivity practically remained constant, it can be seen that $\mathrm{pH}$ after ozonation decreased in only 0.4 units ( Fig.5).

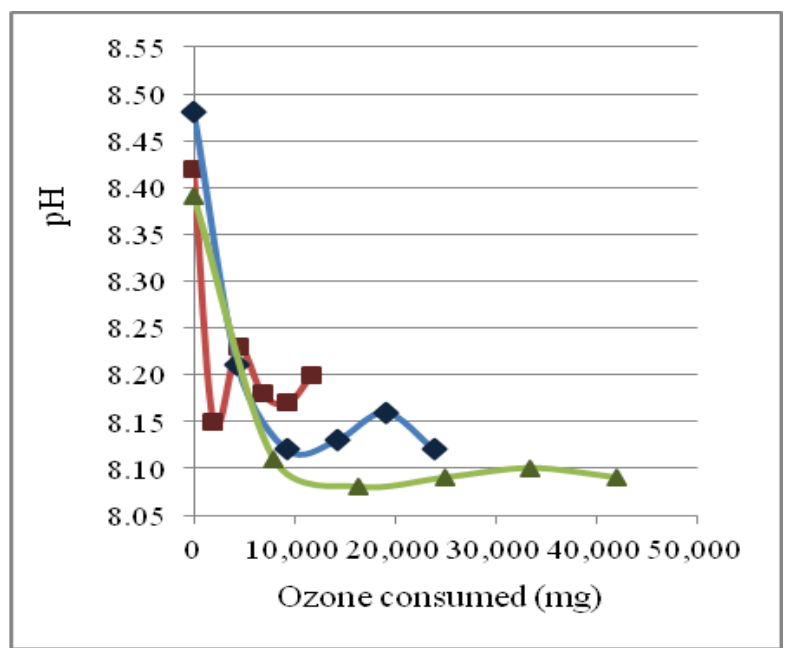

Fig. 5. $\mathrm{pH}$ profile during ozonation (ロ) 2.7\% ozone,( $\bullet$ ) $4.25 \%$ ozone, $(\mathbf{\Delta}) 5.86 \%$ ozone
Conductivity after treatment is slightly reduced (Fig.6). It implied that the Total Dissolved Solid (TDS) in the wastewater was stable. Both parameters were determined along the ozonation reaction as a function of $\mathrm{mg}$ of ozone/L consumed. This result is similar with the previous work done by Sarasa et.al [12]. Ozonation doesn't have any effect in $\mathrm{pH}$ and conductivity, so the treatment doesn't give additional cost to adjust the $\mathrm{pH}$ after the treatment. Moreover, ozonation works better in alkaline medium, since the oxidation capacity of ozone may increase due to the formation of highly reactive hydroxyl radicals $(\mathrm{HO} \bullet)$ with $\mathrm{E}^{\circ}=2.8 \mathrm{eV}$, which can attack the double bonds of dye chemical effectively.

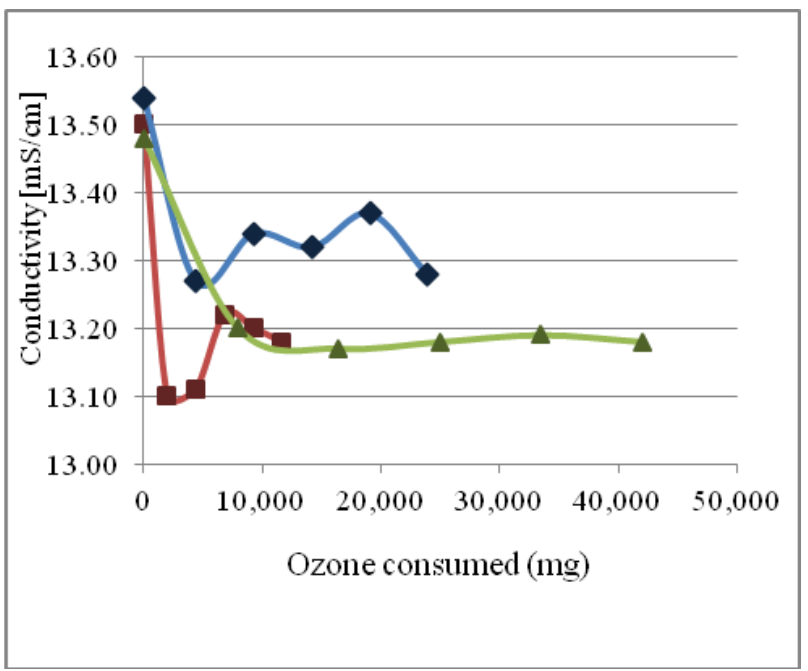

Fig.6. Conductivity profile during ozonation (घ) 2.7\% ozone, (४) $4.2 \%$ ozone, $(\boldsymbol{\Delta}) 5.86 \%$ ozone.

\section{Conclusion}

Ozone treatment is very effective in removing compounds derived from yarn dyeing manufacture, The optimum performance of ozonation was 23 minutes of space time with $1150 \mathrm{~mL}$ reactor volume, $50 \mathrm{~mL} / \mathrm{min}$ volumetric flow rate and $5.86 \% \mathrm{~mol} / \mathrm{mol}$ of ozone. The pseudo first order kinetic constant was $0.053 \mathrm{~min}^{-1}$. There is no significant change of $\mathrm{pH}$ and conductivity during the ozonation process.

We thank to BA yarn dyeing manufacture for financial support for the project and Laboratory of Reaction Engineering staffs for their help in carrying out this study.

\section{References}

1. N. Azbar, T. Yonar, K. Kestioglu, Chemosphere 55,35-43 (2004)

2. R. G. Saratale. G. D. Saratale, J. S Chang, S. P. Govindwar, J. Taiwan Inst. Chem. Eng., 42,138-157 (2011)

3. G. R. P. Malpass, D. W. Miwa, D. A. Mortari, S. A. S. Macado, A. J. Motheo, Water Res., 41, 2969-2977 (2007)

4. J. C. Cardoso, G. G. Bessegato, M. V. B. Zanoni, Water Res., 98, 39-46 (2016) 
5. P. R. Gogate, A. B. Pandit, Adv. Environ. Res., 8, 501-551 (2004)

6. Q. Ruijuan, X. Bingzhe, M. Lingjun, W. Liansheng, W. Zunyao, Water Res., 68, 316-327 (2015)

7. A. M. Dore, N. Merlet, B. Legube, J. P. Croue , Ozone Sci. Eng., 10, 153-172(1988)

8. L. Riadi, W. Ferydhiawati, L. D. S. Loeman, Reaktor, 15, 73-78 (2014).

9. APHA, Standard Methods for the Examination of Water and Wastewater (American Public Health Association, 1998)

10.H. S. Fogler, Essentials of Chemical Reaction Engineering (Prentice Hall, 2011)

11. L. Riadi, A. Altway, S. M. Vania, A. Widyasayogo, Journal WPT, 12, 690-697(2017)

12. J. Sarasa, M. P. Roche, M. P. Ormad, E. Gimeno, A. Puig, J. L. Ovelleiro, Water Res., 32, 2721-2727 (1998) 